\title{
Study of a parallel algorithm in liquid front propagation for Ceará's soils using the finite difference method ${ }^{1}$
}

\section{Estudo de um algorítmo paralelo em frentes de propagação líquidas para solos do Ceará usando o método de diferenças finitas}

\author{
Paulo Alexandre Costa Rocha ${ }^{2 *}$; Daniel Albiero ${ }^{3}$; \\ Maria Eugênia Vieira da Silva ${ }^{2}$; Ernesto da Silva Pitombeira ${ }^{4}$
}

\begin{abstract}
This work presents a numerical model to simulate the propagation of a liquid front in unsaturated soils. The governing flow equations were discretized using centered finite differences for the space coordinate and backward differences for the time coordinate. The generated scheme is fully implicit, but "lagging the non-linearities" as referred to the determination of the soil characteristic properties as function of the hydraulic head. The soil properties, moisture content and the unsaturated hydraulic conductivity, were curve fitted for two types of soil (Alluvial Eutrophic and Red-Yellow Podsol) found in the Northeast region of Brazil. The results show that the Alluvial Eutrophic liquid front diffuses faster than the RedYellow Podsol front. The use of a parallel algorithm showed that it can be indicated for bigger problems (2-D), where the processing speed gain can reach values between 2-3 times, against simple problems (1-D).
\end{abstract}

Key words: Groundwater, Richards' equation, numerical simulation, speed up

\section{Resumo}

Este trabalho apresenta um modelo numérico para simular a propagação de uma frente de onda líquida em solos insaturados. As equações de governo do fluxo de água foram discretizadas usando o método das diferenças finitas centradas para as coordenadas de espaço e diferenças atrasadas para a coordenada de tempo. O esquema gerado é completamente implícito, mas as "influências das não linearidades" foram referidas na determinação das propriedades características do solo como função do recalque hidráulico. As propriedades do solo, teor de água e condutividade hidráulica insaturada foram representadas por curvas de regressão para dois tipos de solos (Aluvial Eutrófico e Podzólico Vermelho Amarelo) normalmente encontrados na região Nordeste do Brasil. Os resultados mostraram que a frente de onda do solo Aluvial Eutrófico difunde-se mais rápido do que o solo Podzólico Vermelho Amarelo. O uso do algoritmo paralelo mostrou-se adequado a grandes problemas na simulação $2-\mathrm{D}$, onde a velocidade de processamento pode alcançar valores entre 2-3 vezes maiores do que problemas simples (1-D).

Palavras-chave: Equações de richards, simulação numérica, águas subterrâneas

\footnotetext{
${ }^{1}$ Post Graduate Program in Mechanical Engineering. Federal University of Ceará, UFC, Technological Centre, Department of Mechanical Engineering, Av. Mister Hull, 2977, Campus do Pici, Bloco 714, Zip Code: 60455-760, Fortaleza, CE, Brazil.

${ }^{2}$ Profs. of Mechanical Engineering, UFC, Fortaleza, CE, Brazil. E-mail: paulo.rocha@ufc.br; eugenia@ufc.br

${ }^{3}$ Prof. of Agricultural Engineering, UFC, Fortaleza, CE, Brazil. E-mail: daniel.albiero@gmail.com

${ }^{4}$ Prof. of Water Resources, UFC, Fortaleza, CE, Brazil. E-mail: glauber@ufc.br

* Author for corespondence
} 


\section{Introduction}

The study of infiltration processes is very important in many technological and environmental applications, particularly in water resources research, in the determination of liquid fronts propagation in soils. The literature in this area is very wide (ZACHMANN, 1978; ZACHMANN; DUCHATEAU; KLUTE, 1981; ROSS, 1990; CELIA; BOULOUTAS, 1990). The knowledge of the behavior of a water front propagation in unsaturated soils helps on the rational planning of the water reserves use, e.g. in irrigation systems and in raining areas.

Another example of an infiltration process is the spill of a liquid contaminant on unsaturated porous surfaces that can cause many kinds of ecological problems, particularly if the liquid front reaches any underground aquifer. The determination of the contaminating propagation can avoid larger environmental injuries and help the recuperation of the region.

The prediction of groundwater flow and contaminant transport from mathematical models deals with considerable uncertainty due to the presence of heterogeneities in natural soil formations (Aguire and Highighi, 2002). The principles of continuity of mass and momentum or energy may be applied to describe overland flow conditions in surface irrigation systems (SHAYYA; BRALTS; SEGERLIND, 1993).

The understanding of hydrological processes at watershed scale is an important task in order to optimize management of the available surface water and groundwater resources, mainly the mechanisms overland flow and perched zones of saturated soil and regolith water (NUÑES-GONZALEZ et al., 2011).

If the determination of the liquid front propagation as a function of the space coordinates and time is desired, the mass and momentum conservation equations for an infinitesimal control volume of the flow (for a study of a one dimensional finite difference implicit scheme, see Johnsen (1992)) need to be solved. The partial differential equation for the pressure head as a function of the spatial coordinates and time, commonly known as the Richards Equation, which express the mass and momentum balances, needs information about the specific characteristics of the soil. The soil can be characterized using experimental expressions based on field measures to estimate the moisture content and the hydraulic conductivity, as a function of the pressure head. We also have to define proper boundary and initial conditions for the solution of the system.

Recent interests in unsaturated flow has shifted to the determination of the velocity (specific discharge or flux) in the unsaturated soil because it was realized that this zone acts as a buffer for contaminants that eventually move to the ground water table (MISRA; NIEBER, 2004).

The partial differential equation that describes the system is parabolic, of second order, and non linear. And a general analytical solution is not available, except for specific cases, where the equations for the hydraulic conductivity and the moisture content are constant or expressed as special functions (ZACHMANN, 1978).

Accurate and efficient numerical wave approximation is important in many areas of study as liquid front waves, and finite difference methods have the advantage of ease of use as well as high order convergence, but often require a uniform grid, and stable boundary closure can be non-trivial (FERNANDO; HU, 2011).

This work presents a numerical model to determinate the propagation of a water front, in unsteady-state flow in a unsaturated soil, using finite differences to discretize the domain. The program developed includes information about two kind of Cearás soils: The Alluvial Eutrophic and the Red-Yellow Podsol, which have experimental data published in the literature about hydraulic conductivity (BEZERRA, 1998; CORDEIRO, 
1998) and moisture content (D’ÁVILA, 1983; BEZERRA, 1985; SAUNDERS, 1990; FERREIRA, 1990; GOMES FILHO, 1991), commonly known as the characteristic curve. The parallel algorithm was developed in a modular way to easily permit the application of another kind of soils. It was used both in one and two dimensional cases, to permit a comparison of processing speed gains.

\section{Material and methods}

This work was developed in two parts. In the first, a literature search on the experimental data for the moisture content $(\theta)$ as a function of the pressure head $(\psi)$, and the hydraulic conductivity $(K)$ as a function of the moisture content $(\theta)$ was carried out. These data were then statistically studied, and the procedure is presented in the next section. The second part presents the discretization of the Richards equation in both one and two dimensions, using centered finite differences for the spatial derivatives and forward differences for the time derivative, to obtain a fully implicit scheme. This scheme generated a system of equations equivalent to the number of discrete points in the domain, which was solved for the one and two dimensional cases. To carry out the computational work, parallel routines were introduced in the program, basically in three stages: The determination of the initial and boundary conditions, the creation of the linear system of equations and finally its resolution. The processing times were then measured for a different number of processors.

\section{Soils data and characteristics curves}

As already mentioned, the experimental data used to characterize the soil were obtained from the literature published by local authors. The characteristic curves for the both studied soils are presented in the results section.

The experimental data were curve fitted, using non linear regression. The expressions obtained were used a posteriori in the numerical resolution of the Richards equation.

For the two soils studied (Alluvial Eutrophic and Red-Yellow Podsol), these characteristic curves were fitted using the Van Genuchten (1980) model as,

$$
\theta=C_{1}+\frac{C_{2}-C_{3}}{\left[1+\left(C_{4} \cdot \psi \mid\right)^{C_{5}}\right]^{C_{6}}}
$$

where $C_{1}, C_{2}, C_{3}, C_{4}, C_{5}$ e $C_{6}$ are constants determined in the adjust of the experimental curves.

The hydraulic conductivity $(K)$ data as a function of the soil moisture content $(\theta)$ were used in a non linear exponential regression to fit the curves and find a relationship between the hydraulic conductivity $(K)$ and the pressure head $(\psi)$ for the two soils in study.

\section{Description and discretization of the problem}

Using the mass and momentum conservation laws in an infinitesimal control volume, the liquid flow in an unsaturated media, the Richards equation, is presented (ZACHMANN; DUCHATEAU; KLUTE, 1981; CELIA; BOULOUTAS, 1990; ROSS, 1990) as,

$$
\frac{\partial}{\partial z}\left[K_{z}(\psi)\left(\frac{\partial \psi}{\partial z}+1\right)\right]=C(\psi) \frac{\partial \psi}{\partial t}
$$

$$
\frac{\partial}{\partial x}\left(K_{x}(\psi) \frac{\partial \psi}{\partial x}\right)+\frac{\partial}{\partial z}\left[K_{z}(\psi)\left(\frac{\partial \psi}{\partial z}+1\right)\right]=C(\psi) \frac{\partial \psi}{\partial t}
$$

where the Darcy's model was applied. This model relates the liquid flow with its hydraulic conductivity and the gradient of hydraulic head as

$$
q=-K \nabla \cdot(h-z)
$$


The expressions (2) and (3) are second order parabolic partial differential equations. For the hydraulic conductivity and moisture content expressions used, equations (2) and (3) are nonlinear, with no analytical solution. Two Dirichlet boundary conditions and an initial condition were used. For the one dimensional case, these conditions are,

$$
\begin{array}{lc}
\psi(z, 0)=\psi_{0}, & 0<z<z_{L} \\
\psi(0, t)=\psi_{1}, & t>0 \\
\psi\left(z_{L}, t\right)=\psi_{L}, &
\end{array}
$$

where for the numerical simulation, the values $\psi_{0}=$ $-61,5 \mathrm{~cm}, \psi_{1}=-20,7 \mathrm{~cm}, \psi_{L}=-61,5 \mathrm{~cm}$ and $z_{L}=$ $100 \mathrm{~cm}$ were used.

Four Dirichlet conditions, and one initial, were used for the two-dimensional case,

$$
\begin{array}{ll}
\psi(x, z, 0)=\psi_{0,} & 0<x<x_{L}, 0<z<z_{L} \\
\psi(0, z, t)=\psi_{0 z}, & \\
\psi\left(x_{L}, z, t\right)=\psi_{L z}, & t>0,0<z<z_{L} \\
\psi(x, 0, t)=\psi_{f i m}, & 0,4 . x_{L} \leq x \leq 0,6 . x_{L} \\
\psi(x, 0, t)=\psi_{x 0^{\prime}} & 0<x<0,4 . x_{L}, 0,6 . x_{L}<x<x_{L} \\
\psi\left(x, z_{L}, t\right)=\psi_{x L^{\prime}}, & t>0,0<x<x_{L}
\end{array}
$$

where the values $\psi_{0}=-61,5 \mathrm{~cm}, \psi_{0 z}=-61,5 \mathrm{~cm}, \psi_{L z}$ $=-61,5 \mathrm{~cm}, \psi_{\text {film }}=-20,7 \mathrm{~cm}, \psi_{x 0}=-61,5 \mathrm{~cm}, \psi_{x L}=$ $-61,5 \mathrm{~cm}, x_{L}=100 \mathrm{~cm}$ and $z_{L}=100 \mathrm{~cm}$ were used in the numerical calculation.

The discretization of the Richards equation was made by centered finite differences for the spatial derivatives and forward differences for the time derivative. The application of these differences on the continuous equations resulted in a fully implicit scheme, and the correspondent discretized forms of (2) and (3) are,

$$
\begin{aligned}
C\left(\psi_{i}^{j}\right) \cdot\left(\psi_{i}^{j+1}-\psi_{i}^{j}\right) \cdot \Delta z & =-K_{i-1 / 2}^{j} \cdot \frac{\psi_{i}^{j+1}-\psi_{i-1}^{j+1}}{\Delta z} \cdot \Delta t+K_{i-1 / 2}^{j} \cdot \Delta t \\
& +K_{i+1 / 2}^{j} \cdot \frac{\psi_{i+1}^{j+1}-\psi_{i}^{j+1}}{\Delta z} \cdot \Delta t-K_{i+1 / 2}^{j} \cdot \Delta t
\end{aligned}
$$

for the one dimension case and

$$
\begin{aligned}
C\left(\psi_{m, i}^{j}\right) \cdot\left(\psi_{m, i}^{j+1}-\psi_{m, i}^{j}\right) \cdot \Delta z \cdot \Delta x & =-K_{m, i-1 / 2}^{j} \cdot \frac{\psi_{m, i}^{j+1}-\psi_{m, i-1}^{j+1}}{\Delta z} \cdot \Delta x \cdot \Delta t+K_{m, i-1 / 2}^{j} \cdot \Delta x \cdot \Delta t \\
& +K_{m, i+1 / 2}^{j} \cdot \frac{\psi_{m, i+1}^{j+1}-\psi_{m, i}^{j+1}}{\Delta z} \cdot \Delta x \cdot \Delta t-K_{m, i+1 / 2}^{j} \cdot \Delta x \cdot \Delta t \\
& +K_{m+1 / 2, i}^{j} \cdot \frac{\psi_{m+1, i}^{j+1}-\psi_{m, i}^{j+1}}{\Delta x} \cdot \Delta z \cdot \Delta t \\
& -K_{m-1 / 2, i}^{j} \cdot \frac{\psi_{m, i}^{j+1}-\psi_{m-1, i}^{j+1}}{\Delta x} \cdot \Delta z \cdot \Delta t
\end{aligned}
$$

for the two-dimensional case.

\section{Numerical solution}

The algorithm developed to solve both problems (one and two dimensions) consisted basically of three subroutines, for each different instant of time:

Subroutine $a$ : definition of the boundary and initial conditions;

Subroutine $b$ : construction of the linear system, which generates one equation per domain point. Since the soil's properties depend upon the pressure head at that instant of time, which are not known, the values of $(\psi)$ used were from the previous instant (lagging in time solution);

Subroutine $c$ : the numerical resolution of the linear system.

This algorithm generated a FORTRAN code which solved the one and two dimensional problems.

\section{Results and Discussion}

\section{Characteristic curves}

The following figures $1(\mathrm{a})$ and 1 (b) presents the characteristic curves for the two soils studied using the experimental data. 
Figure 1. (a) Non linear curve fit for the characteristic curve of the Alluvial Eutrophic soil. Data: Ferreira (1990), (b) Non linear curve fit for the characteristic curve of the Red-Yellow Podsol soil. Data:Gomes Filho (1991).
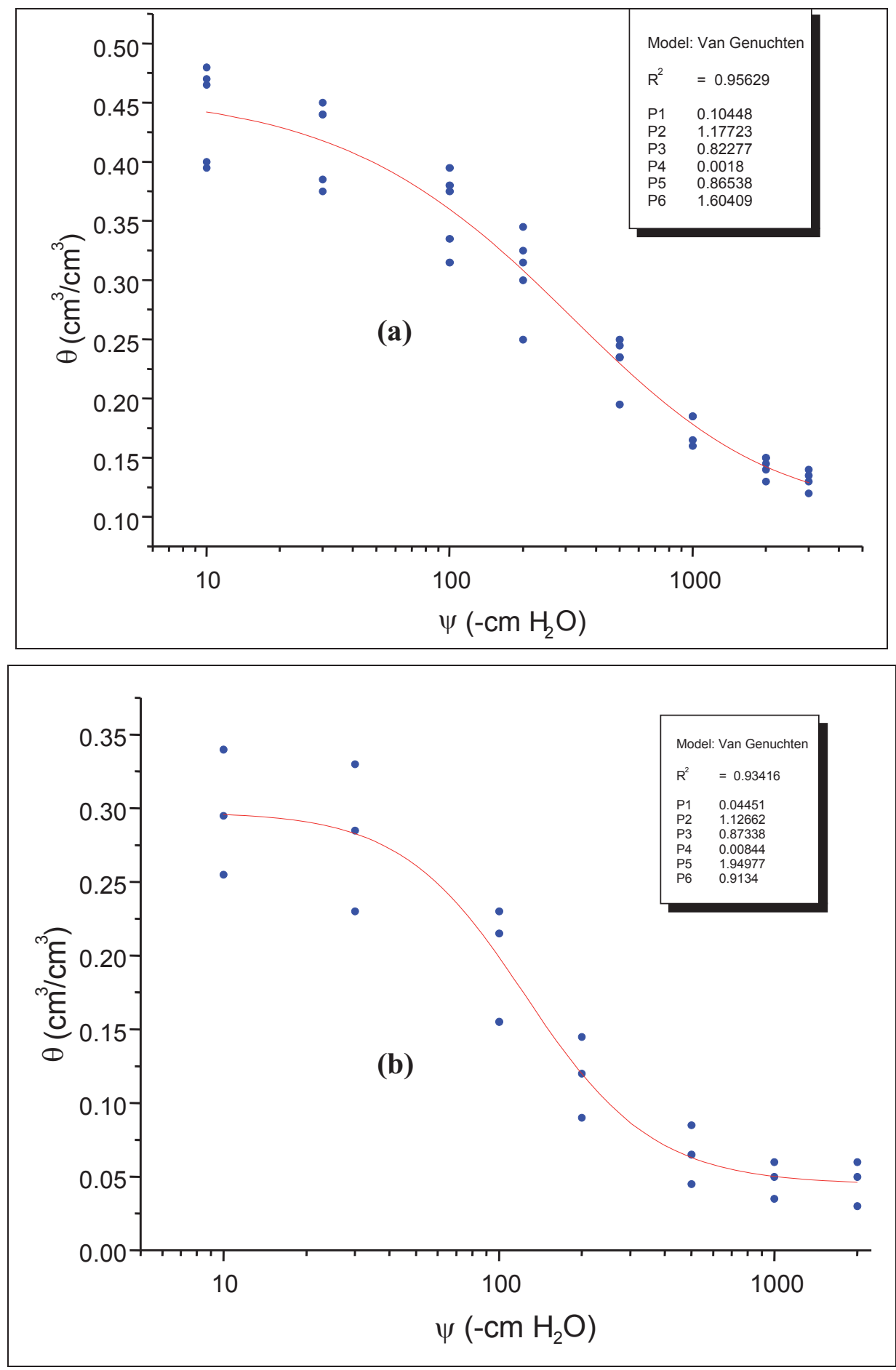

Source: Elaboration of the authors. 
Hydraulic Condutivity (K) versus soil Moisture Content $(\theta)$

The hydraulic conductivity coefficient $(K)$ versus the soil moisture content $(\theta)$ data was treated in an analogous way. Using the same criteria as in the previous section, the works of El-Husny (1979) for the Alluvial Eutrophic soil and Bezerra (1998), for the Red-Yellow Podsol soil were used. The non linear regression model is an exponential growth, which generated the graphs on the Figures $2 \mathrm{a}$ and $2 b$, as well as the following expressions:

For the Alluvial Eutrophic soil (Figure 2(a)),

$$
K(\theta)=0,00003 \cdot e^{\theta / 0,0433}
$$

and for the Red-Yellow Podsol soil (Figure 2(b)),

$$
K(\theta)=2,0213 E-8 . e^{\theta / 0,01648}
$$

It is concluded that the hydraulic conductivity in the Alluvial Eutrophic soil is higher than in the Red-Yellow Podsol soil, in the range of values used as boundary and initial conditions, what will lead to a faster liquid propagation in the first case. It is important to say that the hydraulic conductivity units were converted to SI in equations (10) and (11), once the primary obtained values were in $\mathrm{cm} /$ day, as can be seen in Figure 2.

The curve fit was not so good for the Alluvial soil, as it was for the Red-Yellow Podsol soil, showing a variability of the properties as the depth changes.
As a result of the previous non linear regression, with pressure head values expressed in $\mathrm{cm}$, the following expressions shown were obtained:

For the Alluvial Eutrophic soil (Figure 3 a),

$$
\theta=0,10448+\frac{1,17723-0,82277}{\left[1+(0,0018 \cdot|\psi|)^{0,86538}\right]^{1,60409}}
$$

For the Red-Yellow Podsol soil (Figure 3 b),

$$
\theta=0,04451+\frac{1,12662-0,87338}{\left[1+(0,00844 .|\psi|)^{1,94977}\right]^{0,91134}}
$$

It can be seen that the Alluvial soil retains more moisture than the Red-Yellow Podsol, for equal pressure head values. Even using data from different depths, the curve fit is good, what justifies the use of only one expression for all depths.

\section{Propagation - one dimensional model}

The propagation of the liquid front was simulated, using the discretized form of Richards equation (10) as well as equations (12), (13), (14) and (15). The results show the pressure head profiles $(\psi)$ as a function of the depth $(z)$, for the two soils in study, in several instants of time $(1 \mathrm{~s}, 10 \mathrm{~s}, 100 \mathrm{~s}$, $1.000 \mathrm{~s}, 10.000 \mathrm{~s}, 100.000 \mathrm{~s}$ and $200.000 \mathrm{~s}$ ) as seen in Figures 3(a) and 3(b). 
Figure 2. (a) Non linear regression graph for the Alluvial Euthophic $K(\theta)$. Data: El-Husny (1979), (b) Non linear regression graph for the Red-Yellow Podsol $K(\theta)$. Data: Bezerra (1998).

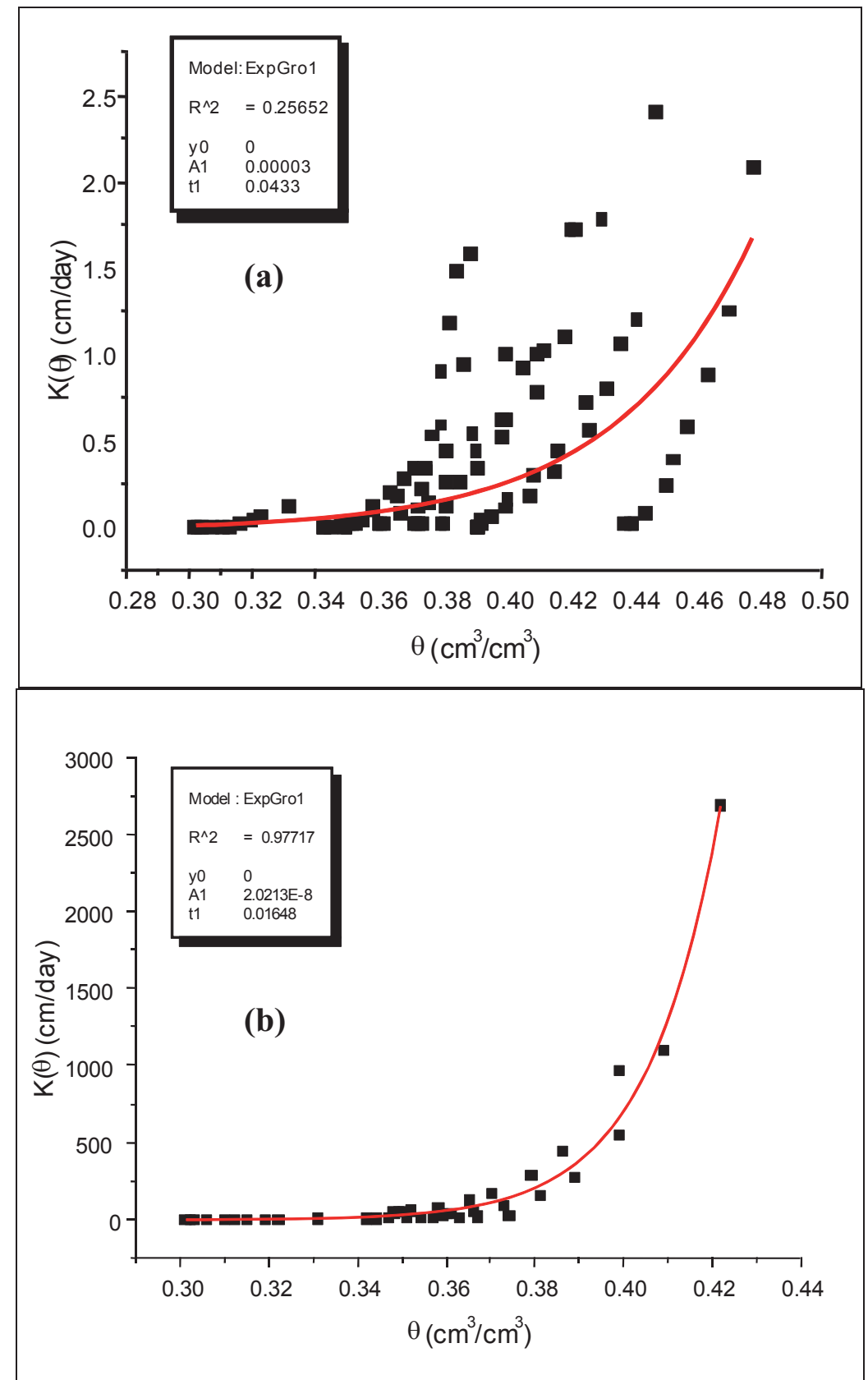

Source: Elaboration of the authors. 
Figure 3. (a) Simulation results of the liquid front propagation for the Alluvial Eutrophic soil with time, (b) Simulation results of the liquid front propagation for the Red-Yellow Podsol soil with time.

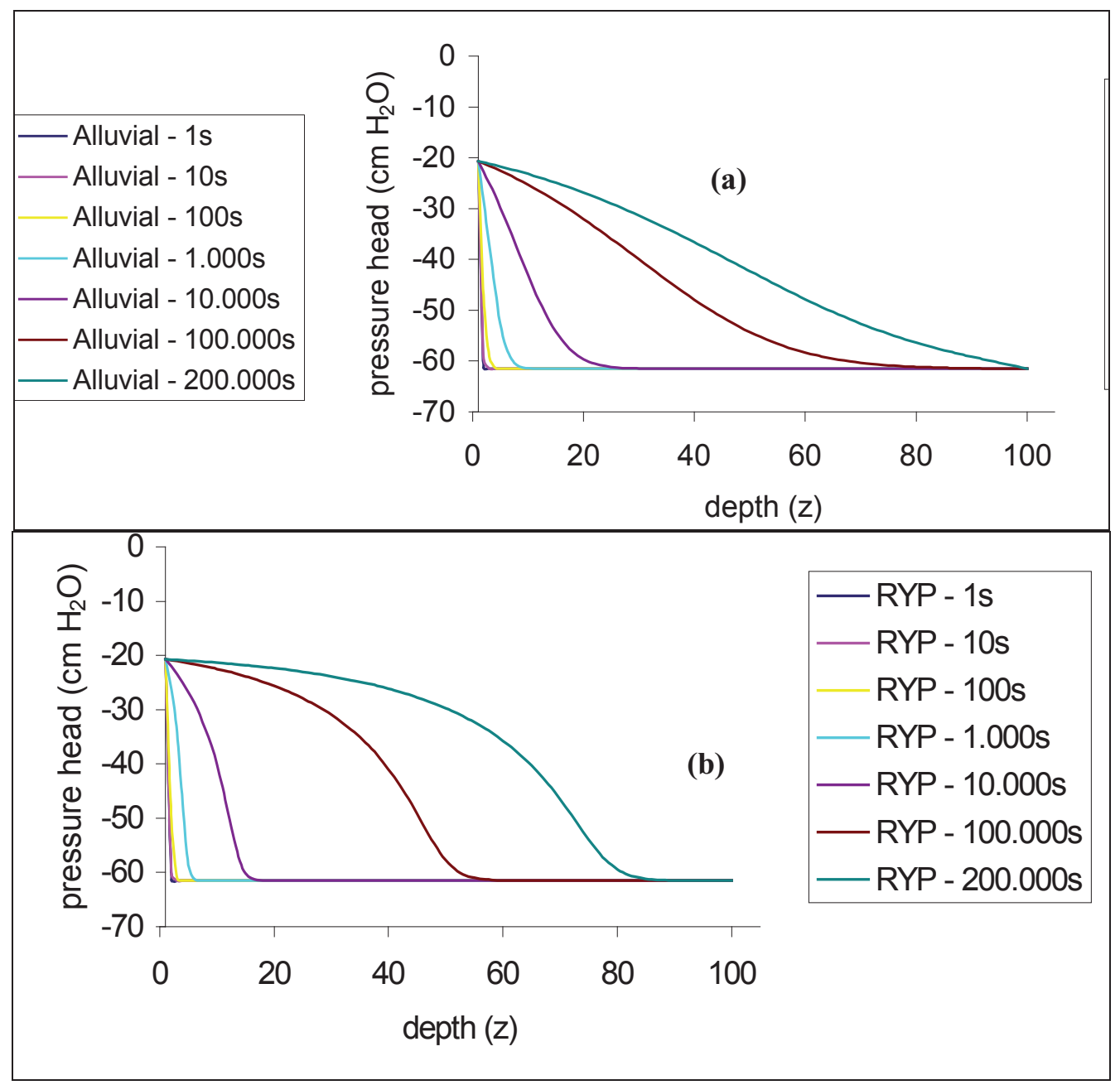

Source: Elaboration of the authors.

Figure 3(a) illustrates the liquid propagation in the Alluvial soil. The front propagates fast, taking 200.000s to reach the domain's bottom. The same instants are presented in Figure 3(b), for the RedYellow Podsol soil. The liquid front propagates slower than in the Alluvial soil, and for $\mathrm{t}=200.000 \mathrm{~s}$ it is still at the $80 \mathrm{~cm}$ depth.

The difference in the propagation velocities can also be noted comparing the pressure head profiles in Figures 3(a) and 3(b). In the Red-Yellow Podsol soil it is not as smooth as in the Alluvial Eutrophic. This means that the soil works as a barrier to the water flow. These numerical results are in accordance to the results presented by El-Husny (1979) and Bezerra (1998), showing that the numerical schemes applied (fully implicit lagging the non linearities) are proper to model the problem. This behavior is expected for fully implicit discretization, because of its unconditional stability. The non linearities provided by the soil matrix, which are generated by the adhesion-cohesion processes between the soil's aggregates and the water, were well predicted by the lagging approach. This procedure gave the necessary computational gains without losing the physical characteristics of the percolation process. 


\section{Propagation - two-dimensional model}

For the boundary and initial conditions of the physical model, the two-dimensional case of the liquid front propagation was simulated, using the discretized Richards equation (11), as well as (12), (13), (14) and (15), applied to the two kinds of soil in study. Results were determined in several instants of time $(1 \mathrm{~s}, 100 \mathrm{~s}, 10.000 \mathrm{~s}$ and $100.000 \mathrm{~s})$ as a function of the $(x)$ and $(z)$ coordinates. These are shown in the Figures $4 \mathrm{a}, \mathrm{b}, \mathrm{c}, \mathrm{d}$.

Figure 4 (a) shows the results at $t=1 \mathrm{~s}$, which practically shows the initial conditions of the problem. Figures 4 (b, c e d) show the front propagation for the other values of time. As in the one-dimensional simulation, the flow velocity in the Alluvial soil is higher than in the Red-Yellow Podsol soil. The numerical solution presented the same stability as in the one-dimensional simulation.

\section{Parallel algorithm and performance}

After the application of algorithm parallelization

on the three main subroutines, the processing time was measured and compared with the oneprocessor run (speed up). This generated the results showed in Figures 5a (one dimension) and 5b (two dimensions).
Once the parallel routines were running in the program, the processing times were measured for a different number of processors and the speed up results were good. Shang, He e Luo (2011) affirm this is a very attractive feature of a parallel algorithm, in addition to the efficient parallelization, the communication between processors and the simplicity of its implementation must be taken into account since the merit of efficient parallelization may be canceled out by large communication cost and extreme human effort required for writing, debugging and modifying a code based on a complex algorithm.

In the allocation of the initial conditions process, the speed up shows the highest values. This happens because there is almost no communication between the processors. A different behavior occurs in the system resolution process, which has higher communications load. As can be seen in Figures 5 , one can even lose computational time if the parallelization is performed with two processors. The results are similar for the one- and two dimensional cases. 
Figure 4. (a) Simulation results of the liquid propagation for the Alluvial Eutrophic soil (left) and the Red-Yellow Podsol soil (right), at $\mathrm{t}=1 \mathrm{~s}$, (b) Simulation results of the liquid propagation for the Alluvial Eutrophic soil (left) and the Red-Yellow Podsol soil (right), at $\mathrm{t}=100 \mathrm{~s}$, (c) Simulation results of the liquid propagation for the Alluvial Eutrophic soil (left) and the Red-Yellow Podsol soil (right), at $t=10.000 \mathrm{~s}$, (d) Simulation results of the liquid propagation for the Alluvial Eutrophic soil (left) and the Red-Yellow Podsol soil (right), at $\mathrm{t}=100.000 \mathrm{~s}$.
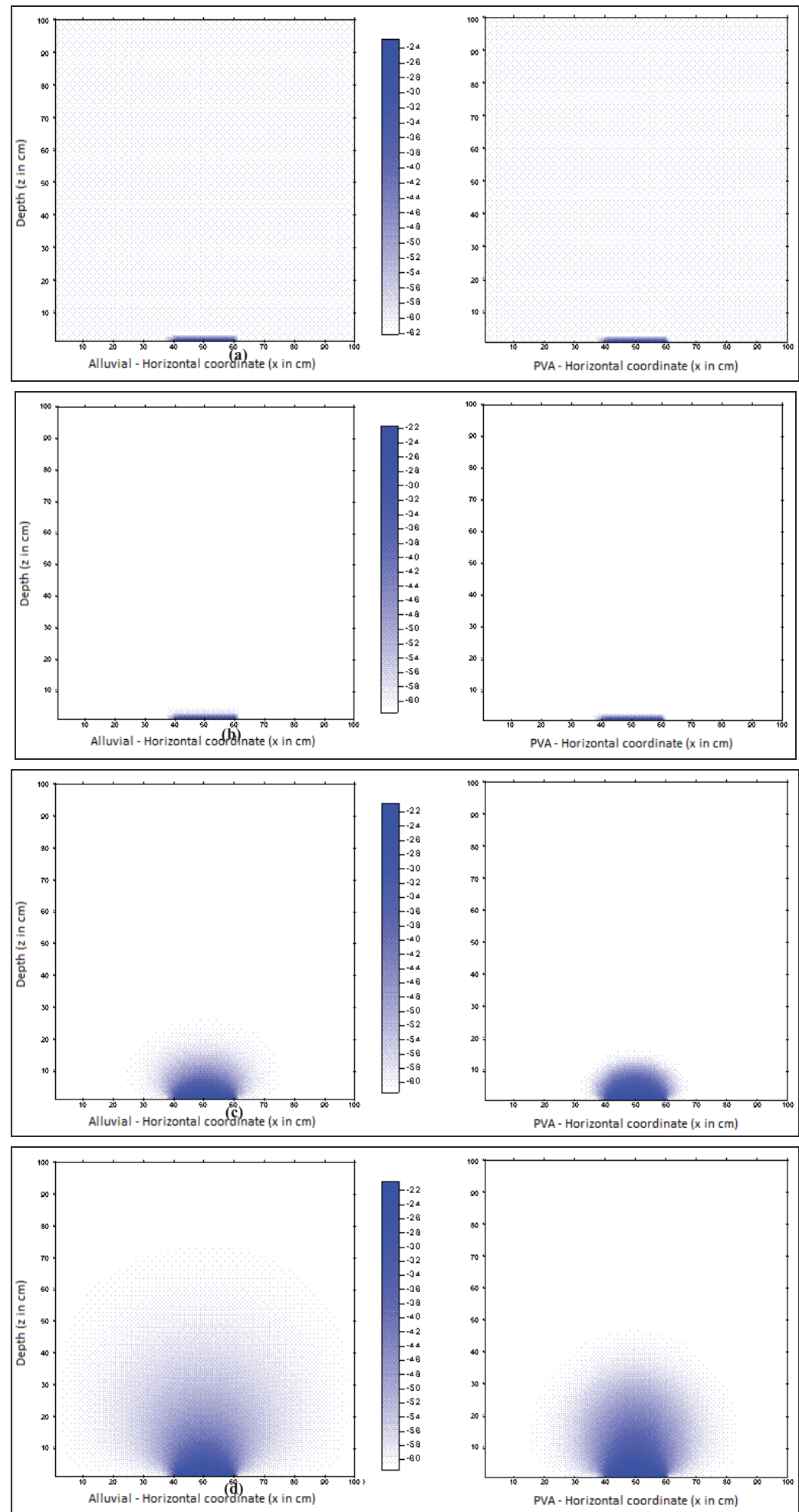

Source: Elaboration of the authors. 
Figure 5. (a) Average speed up graph for 100 (hundred) runnings in a 1.000 .000 points one-dimensional mesh, (b) Average speed up graph for 100 (hundred) runnings in a 1.000x1.000 points two-dimensional mesh.

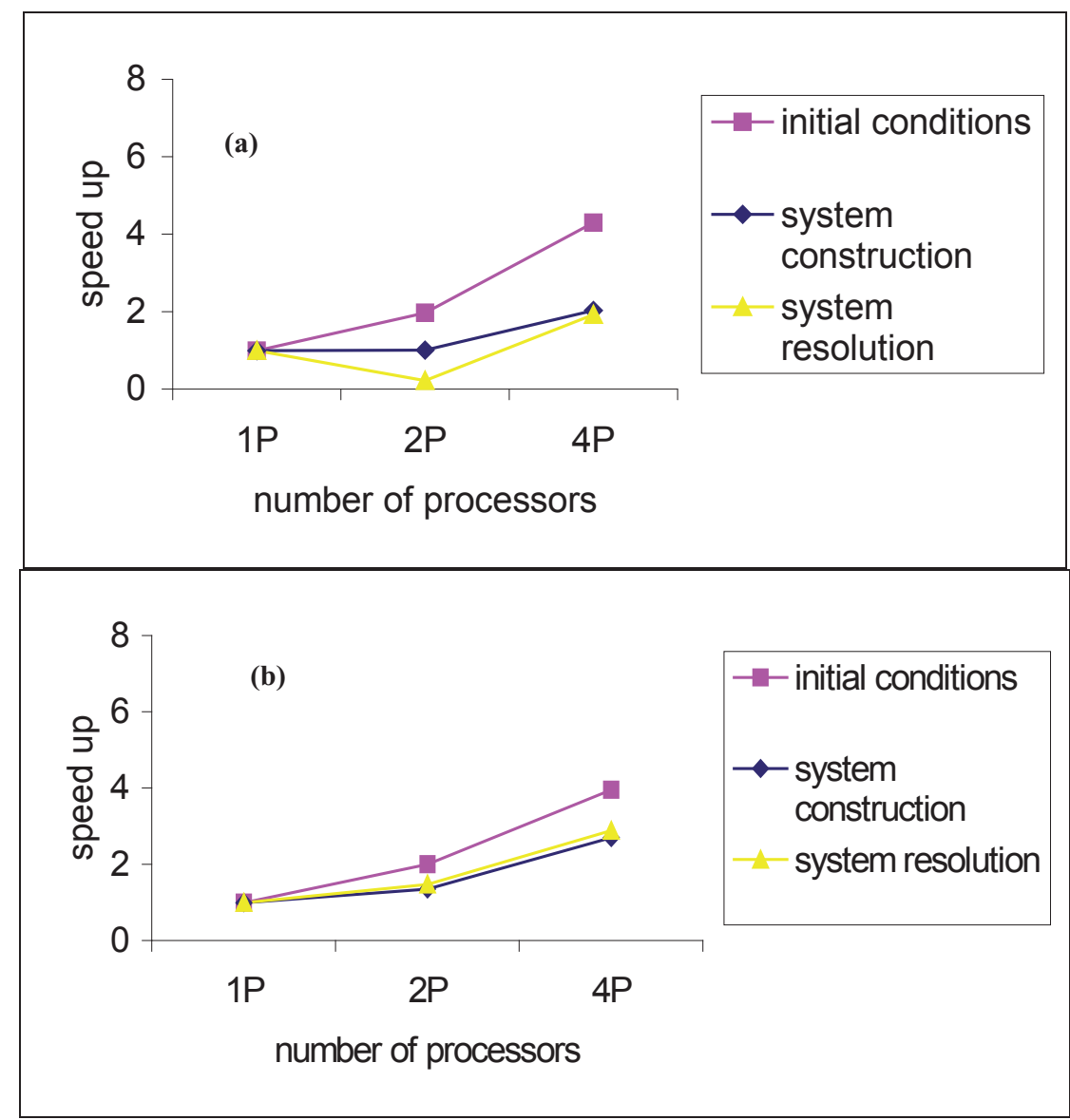

Source: Elaboration of the authors.

\section{Conclusion}

It can be said that the characteristic curves generated for the two kinds of soils studied had a good approximation. This denotes that the use of only one expression for any depth is acceptable, and does give reasonable values $\left(\mathrm{R}^{2} \cong 0,9\right)$. The development of these expressions still give a general vision of the behavior of the different soils studied, which indicates that the Alluvial Eutrophic soil has more potential to accumulate water, both experimentally and numerically.

The adjust of the hydraulic conductivity as a function of the moisture content, for the Alluvial Eutrophic soil, was not so accurate as the one for the Red-Yellow Podsol soil. This indicates that a better adjustment, which could contemplate the depth $(z)$ value, can still be done, and would lead the simulation to still more realistic results. For the Red-Yellow Podsol soil the fitting results were very good, even without consider the influence of the depth.

After the discretization of the equations that described the problem, in the one- and twodimensional forms, and the solution of the linear system, the problem was solved numerically at several instants of time. The solutions obtained and put in graphs showed clearly how the liquid front behaves for different types of soils. These results also indicate the velocity that the moisture spreads 
itself in the soils, showing that the Alluvial Eutrophic gets wet faster than the Red-Yellow Podsol soil, for the same initial pressure head profile.

The parallelization process resulted in speed up curves, presented for the main subroutines of the developed code. These curves showed that the gains in the processing time can be satisfactory, as long as the subroutine has lower communications load, in comparison to the computational one.

\section{Acknowledgements}

We would like to thank Professor David W. Zachmann for providing a copy of his student unpublished work "Johnsen, K. 1992. Comparisons of numerical methods for solving the Richards' equation. (Department of Mathematics, Colorado State University).

\section{References}

BEZERRA, F. M. L. Coeficientes de cultura e de sensibilidade ao estresse hídrico das principais culturas do estado do Ceará. Relatório Final do Projeto 046/96 FUNCAP/FCPC, Universidade Federal do Ceará, 1998.

Efeito do potencial matricial e da época de plantio na produtividade de dois cultivares de feijão-decorda, Vigna unguiculata, (L.) Walp. no Vale do Curu sob regime de irrigação. 1985. Dissertação (Mestrado em Engenharia Agrícola) - Pós-graduação em Engenharia Agrícola, Universidade Federal do Ceará, Ceará.

CELIA, M. A.; BOULOUTAS, E. T. A general massconservative numerical solution for the unsaturated flow equation. Water Resources Research, Urbana, v. 26, n. 7, p. 125-135, 1990.

CORDEIRO, L. G. Influência do déficit hídrico em diferentes estádios fenológicos sobre a produção de feijão caupi (Vigna unguiculata (L.) Walp.). 1998. Dissertação (Mestrado em Engenharia Agrícola) - Pós-graduação em Engenharia Agrícola. Universidade Federal do Ceará, Ceará.

D’ÁVILA, J. H. T. Potencial matricial, adubação e cultivares na produtividade de milho Zea mays, L. 1983. Dissertação (Mestrado em Engenharia Agrícola) - Pós-graduação em Engenharia Agrícola. Universidade Federal do Ceará, Ceará.
EL-HUSNY, E. C. Estudo comparativo de dois métodos de determinação da condutividade hidráulica sob condições de campo. 1979. Dissertação (Mestrado em Engenharia Agrícola) - Pós-graduação em Engenharia Agrícola, Universidade Federal do Ceará, Ceará.

FERNANDO, A. M.; HU, F. Q. DGM-FD: a finite difference scheme based on the discontinuous Galerkin method applied to wave propagation. Journal of Computational Physics London, v. 230, n. 12, p.48714898, 2011.

FERREIRA, M. N. L. Determinação da evapotranspiração atual e potencial da cultura de melancia. 1990. Dissertação (Mestrado em Engenharia Agrícola) - Pós-graduação em Engenharia Agrícola. Universidade Federal do Ceará, Ceará.

GOMES FILHO, R. R. Distribuição de umidade num solo Podzólico Vermelho Amarelo irrigado por gotejamento em condições de campo. 1991. Dissertação (Mestrado em Engenharia Agrícola) - Pós-graduação em Engenharia Agrícola. Universidade Federal do Ceará, Ceará.

JOHNSEN, K. Comparisons of numerical methods for solving the Richards' equation. Unpublished Report. Department of Mathematics, Colorado State University, 1992.

MISRA, D.; NIEBER, J. L. Assessment of mixed finite element method applied to one-dimensional transient unsaturated flow. ASABE Paper: 042072. St. Joseph, Mich: ASABE, 2004.

NUÑES-GONZALES, G.; DOMINGUES-CORTAZAR, M. A.; VENTURA-RAMOS JUNIOR, E.; RAMIREZ, A. I. Modeling the observed hydrograph recession of a small semiarid watershed. Agrociencias, Colpos, v. 45, n. 2, p. 157-164, 2011.

ROSS, P. J. Efficient numerical methods for infiltration using Richards' equation. Water Resources Research, Urbana, v. 26, n. 2, p. 279-290, 1990.

SAUNDERS, L. C. U. Procedimento na determinação da evapotranspiração real utilizando a equação da lei de conservação das massas com as culturas milho e algodão. 1990. Tese (Doutorado em Engenharia Agrícola) - Pós-graduação em Engenharia Agrícola, Universidade Federal do Ceará, Ceará.

SHANG, Y.; HE, Y.; LUO, Z. A comparation of three kinds of local and parallel finite element algorithmis on two-grid discretizations for the stationary Navier-Stokes equations. Computer and Fluids, London, v. 40, n. 2, p. 249-257, 2011. 
SHAYYA, W. H.; BRALTS, V. F.; SEGERLIND, L. J. Kinematic-wave furrow irrigation analysis: a finite element approach. Transactions of the ASABE, St. Joseph, v. 36, n. 6, p. 1733-1742, 1993.

VAN GENUCHTEN, M. T. H. A closed-form equation for predicting the hydraulic conductivity of unsaturated soils Soil Science Society of America Journal, Madison, v. 44, n. 5, p. 892-898, 1980.
ZACHMANN, D. W. A mathematical treatment of infiltration from a line source into an inclined porous medium. Soil Science Society of America Journal Madison, v. 42, n. 5, p. 685-688, 1978.

ZACHMANN, D. W.; DUCHATEAU, P. C.; KLUTE, A. The calibration of the Richards flow equation for a draining column by parameter identification. Soil Science Society of America Journal, Madison, v. 45, n. 6, p. 10121015, 1981. 
